\title{
Assessment of the Influence Systemic Cryotherapy Exerts on Chosen Skin Scores of Patients with Atopic Dermatitis: Pilot Study
}

\author{
Magdalena Kepinska-Szyszkowska $\mathbb{D}^{1},{ }^{1}$ Anna Misiorek ${ }^{(D)},{ }^{1}$ Monika Kapinska-Mrowiecka, \\ Jan Tabak, ${ }^{3}$ and Karolina Malina ${ }^{2}$ \\ ${ }^{1}$ Institute of Applied Sciences, University School of Physical Education in Krakow, Poland \\ ${ }^{2}$ Dermatology Ward, Stefan Żeromski Hospital in Krakow, Poland \\ ${ }^{3}$ Malopolska Centre for Cryotherapy, Al. Pokoju 82 Krakow, Poland
}

Correspondence should be addressed to Magdalena Kepinska-Szyszkowska; makep06@gmail.com

Received 10 March 2020; Revised 5 June 2020; Accepted 17 August 2020; Published 8 September 2020

Academic Editor: Michele Maruccia

Copyright ( 2020 Magdalena Kepinska-Szyszkowska et al. This is an open access article distributed under the Creative Commons Attribution License, which permits unrestricted use, distribution, and reproduction in any medium, provided the original work is properly cited.

\begin{abstract}
Background. One of the most important tasks in the treatment of atopic dermatitis (AD) is alleviation of racking skin dryness and persistent pruritus, because these factors exert a significant influence on worsening patients' quality of life. Cryotherapy being a new form of rehabilitation in $\mathrm{AD}$ may supplement and support a long-term process of $\mathrm{AD}$ treatment, because it has anti-inflammatory and antipruritic effects and exerts a positive influence on the nervous system. Methods. 14 adults (mean age $32 \pm 10.8$ ) with mild to moderate AD were enrolled. WBC (15 treatments in total) took place in winter 2018/2019. Patient skin parameters (hydration of the epidermis, sebum level, and skin $\mathrm{pH}$ level) were measured with probes produced by Courage + Khazaka Electronic GmbH. Results. Changes were observed in the hydration level of the epidermis. The SCORAD index evaluating the AD intensity level also changed (decreased). Conclusion. Due to these properties, hypothesis has been put forward that WBC can be an effective, supporting method in the treatment of AD.
\end{abstract}

\section{Introduction}

A number of factors exert an influence on proper functioning of the skin barrier. These include the level of hydration and skin $\mathrm{pH}$, quantity and composition of intracellular lipids, corneocyte cellular properties, and their cohesion in the cornified layer. Visibly rough and dry skin in individuals with $\mathrm{AD}$ reflects its abnormal picture also in morphology. Corneocyte cohesion increases, and their diameter decreases. The cycle of cell migration from the basal layer to the cornified layer is extended, and a general number of layers in the stratum corneum are increased [1]. Dry skin in atopic patients is associated with abnormal activity of the hydrolipid barrier. One of the reasons for its abnormal function is an increased transepidermal water loss (TEWL), as well as increased pruritus and inflammation [2]. In cases of exacerbated dermatitis, TEWL may increase even four times, whereas during remission even twice, as compared with healthy skin [3].
In atopic skin, there is also another distribution of lipids; they are packed hexagonally. Moreover, the level of sphingosine (a component of many lipids) in an undamaged and damaged stratum corneum in patients with $\mathrm{AD}$ is significantly decreased as compared with that in healthy patients from a control group [4]. Skin $\mathrm{pH}$ also plays a role in proper functioning of the epidermal barrier. Proper $\mathrm{pH}$ of the skin surface and its deeper layer conditions maintain proper physiological flora and antimicrobial immunity of the skin. Proper skin $\mathrm{pH}$ should be slightly acidic. In women, it should be 4.5-5.9, whereas in men, it should be a little lower, i.e., 4.3-5.9. Studies have proven that skin $\mathrm{pH}$ increases in individuals with $\mathrm{AD}[1,5,6]$.

One of the most important tasks in the treatment of $\mathrm{AD}$ is alleviation of racking skin dryness and persistent pruritus, because these factors exert a significant influence on worsening patients' quality of life. Topical therapy of AD includes proper skin care, avoiding or limiting factors that exacerbate 
the symptoms, and, in cases of superinfections, proper antibiotic therapy and use of preparations containing calcineurin inhibitors or glucocorticosteroids [7].

Whole-body cryotherapy (WBC) relies on a short stay (23 minutes) in a special cryochamber at very low ambient temperature. These treatments have a positive effect on the endocrine, nervous, and immune systems. They also accelerate tissue regeneration, relieve pain, and suppress inflammation after intense physical effort [8]. Cryotherapy being a new form of rehabilitation in $\mathrm{AD}$ may supplement and support a long-term process of AD treatment, because it also has anti-inflammatory and antipruritic effects. Cryotherapy does not show any adverse reactions, and that is why it is a safe method for treating patients. As compared with phototherapy, it may be combined with other treatment methods, e.g., cyclosporin or tacrolimus. These treatments do not carry the risk for developing skin cancers, which could be side effects while using phototherapy [9]. The aim of the study was to evaluate changes in selected skin parameters after WBC in patients with AD.

\section{Materials and Methods}

2.1. Characteristics of Patients. The subjects were adults, who live in a big city and suffer from AD for a long time. Most of them had exacerbations of the disease every few months, and the severity of $\mathrm{AD}$ showed annual seasonality. The following inclusion criteria were used in the study: age above 18 years, no contraindications to WBC procedures, and clinically diagnosed with $\mathrm{AD}$ (with mild to moderate $\mathrm{AD}$ ). Exclusion criteria of the research were as follows: lack of informed consent for research; patients with $\mathrm{AD}$ treated with phototherapy, cyclosporine A, and oral corticosteroids, which are topical calcineurin inhibitors such as pimecrolimus and tacrolimus; patients during or after immunotherapy; children and adolescents under 18 years of age; breastfeeding mothers and pregnant women; and patients with inflammatory, infectious, and autoimmune diseases and cancer. On the basis of a questionnaire completed by patients in the presence of a dermatologist, an analysis of $\mathrm{AD}$ was made. The questionnaire included basic information such as disease duration, symptoms, treatment, diagnostics for allergies, and family history. The next stage involved assessment of the level of $\mathrm{AD}$ advancements on the basis of the Scoring Atopic Dermatitis (SCORAD) index. Also, major and minor AD criteria presented by Hanifin and Rajka were taken into consideration [10].

Fourteen adults (mean age $32 \pm 10.8,7$ men and 7 women) with mild to moderate AD were enrolled. The study was carried out in accordance with the Declaration of Helsinki. The methodology of the scientific project was approved by the Bioethics Committee at the District Medical Chamber in Krakow, Poland (opinion no. 239/KBL/OIL/2018). The study was registered at ClinicalTrials.gov under the number NCT03761199.

2.2. Measurement of Skin Parameters. Patient skin parameters were measured with probes produced by Courage + Khazaka Electronic $\mathrm{GmbH}$. The level of hydration of the epidermis was examined with Corneometer ${ }^{\circledR}$ CM 825; Sebumeter ${ }^{\circledR}$ SM 815 was used to determine sebum levels of the skin, and SkinpH-Meter PH 905 was applied to determine the skin pH level. There were 4 measurements of skin parameters performed in the following way: prior to the first cryotherapy treatment, directly after the first treatment, after the $15^{\text {th }}$ treatment, and after 3 weeks from the moment when the therapy was discontinued. The measurement was performed on the involved skin on the patient's hand (dorsal side) and on areas free from lesions on the forearm (inner side). A SCORAD index was used during the series of treatments to assess the changes in intensity levels of the skin lesions. Measurements were taken before the treatments, after the $15^{\text {th }}$ treatments, and 3 weeks from the day when examination came to an end.

2.3. Whole-Body Cryotherapy Procedures. Whole-body cryotherapy (15 treatments in total, once a day) took place at the Malopolska Centre for Cryotherapy, Al. Pokoju 82, Krakow, Poland. Having been consulted with a physician to exclude contraindications for WBC, patients were referred for treatments. Patients entered the cryogenic chamber wearing special shoes, thick shocks, shorts, gloves, and a headwear. In order to get the body used to low temperatures, patients spend 1.5 minutes in the main chamber on the first day. The next day, it was 2 minutes and then 3 minutes till the end of the therapy. WBC took place in winter 2018/2019. Patients did not use local anti-inflammatory preparations and systemic antihistamine drugs a week before the therapy and during the course of the study.

Participants started to cool the body down in the vestibule in which the temperature was $-60^{\circ} \mathrm{C}$ ( 30 seconds). Then, they proceeded to the main chamber, where the temperature was $-120^{\circ} \mathrm{C}$. Patients remained under continual control by a person handling the device thanks to thermal glass and intrachamber monitoring. Thanks to a phonic contact, it was possible to inform patients about the time remaining till the end of the treatment. In case of feeling unwell, patients could use an alarm button as well as an exit devise designed for opening the door from the inside (Figures 1 and 2).

2.4. Statistical Analysis. Due to a small number of participants and because of the lack of normal data distribution, nonparametric statistics (Wilcoxon signed-rank test) was used for comparisons of posttreatment data with the baseline. Median $(M)$ and the value of the lower and the upper quartile (Q25Q75) are reported in the subsequent sections and throughout the tables. A $p$ value of less than 0.05 was considered statistically significant. All statistical analyses were performed with the Statistica 13 software (StatSoft, Inc., USA).

\section{Results}

Eight of fourteen patients completed the treatment period ( 5 women and 3 men). Of the patients who left the study, 2 patients discontinued owing to worsening dermatitis and the other 4 for reasons not related to skin condition. There were almost no differences in measurements of sebum skin levels in the measured areas of both the involved skin and skin without lesions. An exception is a measurement of the skin without atopic lesions, whose sebum level decreased; 


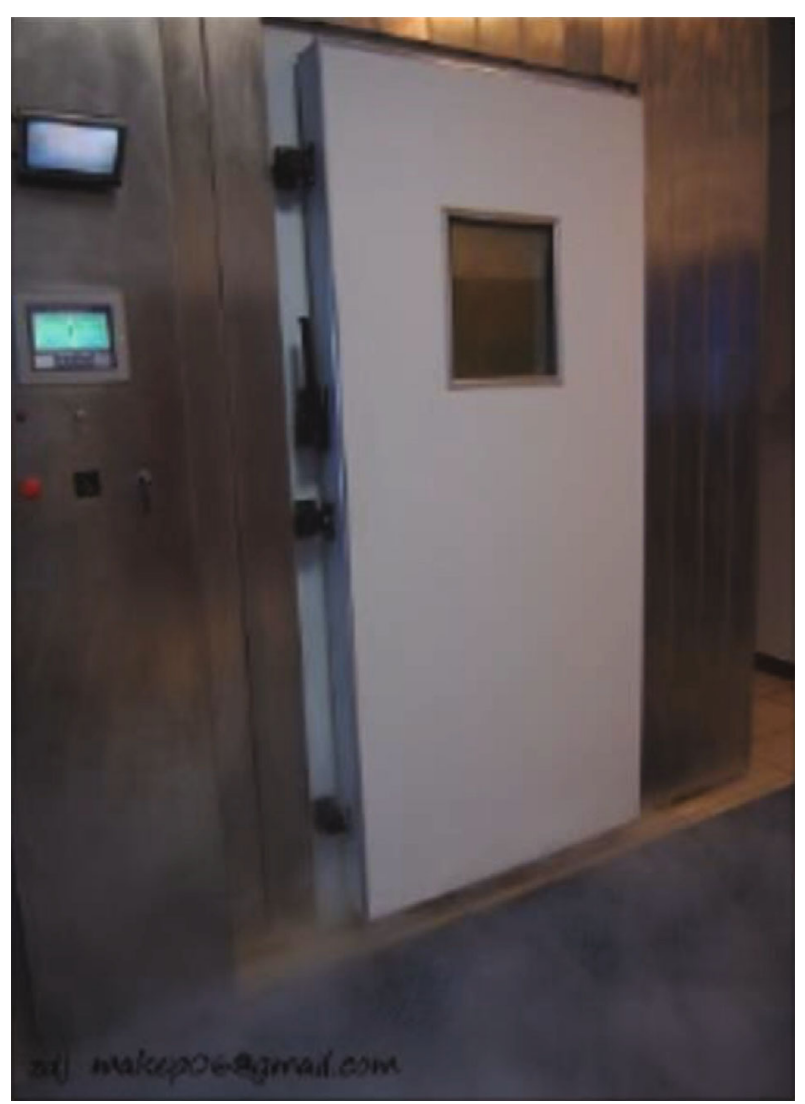

FIGURE 1: Entrance to the cryochamber (author's photograph).

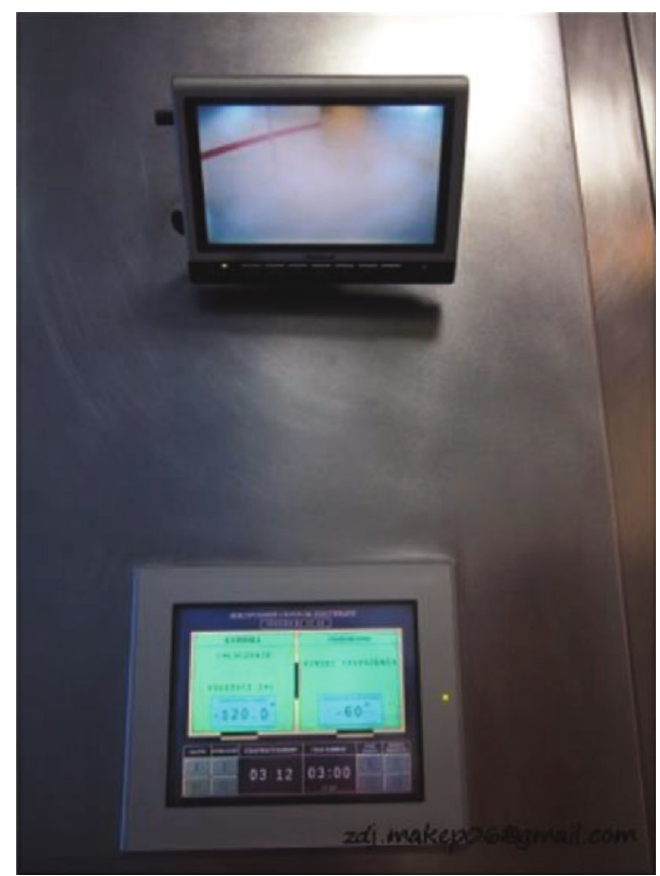

Figure 2: Camera and monitor indicating temperature inside the chamber (author's photograph). the result was statistically significant in comparison to measurement 4 to measurement $1(p=0.043)$. Changes in the level of hydration of the epidermis of both healthy skin and the skin with $\mathrm{AD}$ symptoms were also observed. In places where atopy symptoms occurred, the skin was drier as compared with the healthy area (Table 1). Furthermore, the results indicate that hydration of the epidermis in the involved skin increased directly after the $1^{\text {st }}$ treatment and after 3 weeks from the last treatment ( 2 vs. $1(p=0.015)$ and 4 vs. $1(p=0.010)$, respectively) (Table 2$)$.

There were no statistically significant differences in the $\mathrm{pH}$ level, both in the area of atopic lesions and in healthy skin. The SCORAD index evaluating the AD intensity level changed. The difference between the first (36.5 points) and the last (25.23 points) score was statistically significant $(p=0.011)$ (Figure 3$)$.

\section{Discussion}

Applying a series of $\mathrm{WBC}$ in the treatment of $\mathrm{AD}$ is a new and unconventional solution. Studies of Klimenko et al. [9] are the only ones that evaluate the influence of $\mathrm{WBC}$ on the condition of patients with mild and moderate AD. A comparison of our studies with those mentioned above seems to be significant for this paper since it constitutes a reference to a larger group of patients. The patients used neither local anti-inflammatory preparations nor systemic antihistamine drugs a week before the therapy commencement and also during the course of the studies. Treatments in the cryochamber took place 3 times a week for a month. The level of transepidermal water loss (TEWL) was measured with VapoMeter. The mean TEWL value improved from $58.8 \mathrm{~g} / \mathrm{m}^{2} / \mathrm{h}$ to $47.4 \mathrm{~g} / \mathrm{m}^{2} / \mathrm{h}$, which means better hydration of the epidermis [9]. In our studies, there were similar positive results, epidermal hydration increased directly after the first treatments in the involved skin, and also this effect was seen in 3 weeks after the end of the treatment. However, when comparing skin results with atopic changes to healthy skin results, the skin with atopic lesions was still very dry after cryotherapy treatments. According to studies by Knor et al. [1], skin with atopic lesions has a lower level of hydration than healthy skin of $\mathrm{AD}$ patients.

On the basis of an analysis of the collected data, it may be concluded that within the measurement area of the skin with lesions and uninvolved skin, almost no differences in sebum levels of the skin were noted. An exception is the measurement of the skin without atopic lesions whose sebum dropped in comparison to measurement 4 (3 weeks after the last $\mathrm{WBC}$ ) to measurement 1 (before the first treatment of WBC) which means that the skin was very dry. Skin sebum levels in the patients, as it is presented above, did not improve after the treatments involving WBC. In line with epidemiological data, skin lesions caused by irritation appear more often in winter than in other seasons. Cold and dry air contributes to skin dryness and damage of the epidermal barrier [11]. It might be the reason behind the lack of improvement in skin sebum levels in our studies.

It was shown that there appears an increase in skin $\mathrm{pH}$ in patients with $\mathrm{AD}$. A study conducted by Knor et al. [1] 
TABLE 1: The skin hydration measured before the first treatment (1), immediately after the first (2), after the 15th treatment (3), and after 3 weeks from the end of WBC (4) on healthy and diseased skin.

\begin{tabular}{|c|c|c|c|}
\hline \multirow[b]{2}{*}{ Measurement no. } & \multicolumn{2}{|c|}{ Hydration level } & \multirow[b]{2}{*}{$p$} \\
\hline & $\begin{array}{l}\text { Forearm without atopic changes (F) } \\
\qquad M(\mathrm{Q} 25-\mathrm{Q} 75)\end{array}$ & $\begin{array}{c}\text { Hand with atopic changes }(\mathrm{H}) \\
M(\mathrm{Q} 25-\mathrm{Q} 75)\end{array}$ & \\
\hline 1 & $29.9(28.1-32.3)$ & $10(8-12.1)$ & $\begin{array}{c}1 \mathrm{~F} \text { vs. } 1 \mathrm{H} \\
0.011 \\
1 \mathrm{~F} \text { vs. } 2 \mathrm{H} \\
0.011 \\
1 \mathrm{Fvs} .3 \mathrm{H} \\
0.011 \\
1 \mathrm{~F} \text { vs. } 4 \mathrm{H} \\
0.011\end{array}$ \\
\hline 2 & $28.1(22.4-29.4)$ & $10.5(9.4-13.5)$ & $\begin{array}{c}2 \mathrm{~F} \text { vs. } 1 \mathrm{H} \\
0.011 \\
2 \mathrm{~F} \text { vs. } 2 \mathrm{H} \\
0.025 \\
2 \mathrm{~F} \text { vs. } 3 \mathrm{H} \\
0.011 \\
2 \mathrm{~F} \text { vs. } 4 \mathrm{H} \\
0.011\end{array}$ \\
\hline 3 & $28.2(25.8-30.3)$ & $9.9(7.9-16.4)$ & $\begin{array}{c}3 \mathrm{~F} \text { vs. } 1 \mathrm{H} \\
0.017 \\
3 \mathrm{~F} \text { vs. } 2 \mathrm{H} \\
0.011 \\
3 \mathrm{~F} \text { vs. } 3 \mathrm{H} \\
0.011 \\
\text { 3F vs. } 4 \mathrm{H} \\
\mathrm{NS}\end{array}$ \\
\hline 4 & $23.5(14.5-30.1)$ & $14.8(9.5-20.0)$ & $\begin{array}{c}\text { 4F vs. } 1 \mathrm{H} \\
0.011 \\
\text { 4F vs. } 2 \mathrm{H} \\
0.035 \\
\text { 4F vs. } 3 \mathrm{H} \\
0.011 \\
\text { 4F vs. } 4 \mathrm{H} \\
\mathrm{NS}\end{array}$ \\
\hline
\end{tabular}

1-4: measurement number; vs.: versus; NS: nonstatistical; F: forearm; H: hand; M: median; Q25-Q75: the value of the lower and the upper quartile. $p<0.05$.

showed a higher $\mathrm{pH}$ concentration in individuals with atopic eczema as compared with individuals with perilesional and healthy skin and the control group [1]. Our studies also showed a slightly higher value in the $\mathrm{pH}$ on the hand with atopic eczema to compare with the forearm without lesions before the first treatment of WBC. In our studies, no changes in skin $\mathrm{pH}$ values (in both measured areas) were found after all WBC treatments and after 3 weeks from the last treatment. Skrzek et al. [12] also confirm the lack of influence of a series of $\mathrm{WBC}$ on the $\mathrm{pH}$ level in healthy people. It can be concluded that cryotherapy does not affect the skin $\mathrm{pH}$ [12].

In the presented results, a mean SCORAD index decreased after cryotherapy treatments and 3 weeks after the last treatment. Klimenko et al. [9] also observed decrease in the SCORAD index after a series of WBC treatments. According to the authors, cryotherapy of the entire body shows a steroid effect with additional statistically and clinically significant improvements in the case of pruritus and sleep [9]. Improvements in lesions in the patients (SCORAD index) might have also been influenced by good mood that accompanies people regularly using treatments in a cryochamber. When stressed, AD patients often experience pruritus. The neuroendocrine system and the immune system are connected to one another, and moreover, there are interactions between these systems and the skin. Stress exerts a negative influence on dermatoses, especially the inflammatory ones, such as AD [13]. Rymaszewska et al. [14] in their studies confirmed the efficacy of WBC for patients suffering from episodes of depression and anxiety. There was an improvement in the well-being and quality of life of the patients [14].

The beneficial changes after WBC treatments observed in our studies (changes in hydration of the epidermis and changes in the SCORAD index) may also result from the anti-inflammatory effect and from the effect on oxidative stress of WBC. Research shows that cryotherapy improves the body's antioxidant capacity and can be used as an adjunctive therapy in the treatment of diseases with oxidative stress [15]. According to Stanek et al. [16] after a series of $10 \mathrm{WBC}$ treatments, the level of C-reactive protein and mucoproteins decreased in patients with ankylosing spondylitis (AS). In 
TABLE 2: The skin parameters measured before the first treatment (1), immediately after the first (2), after the 15th treatment (3), and after 3 weeks from the end of WBC therapy (4) on healthy and diseased skin.

\begin{tabular}{|c|c|c|c|c|c|}
\hline \multirow{2}{*}{ Part of the body } & \multicolumn{4}{|c|}{ Measurement } & \multirow[b]{2}{*}{$p$} \\
\hline & 1 & 2 & 3 & 4 & \\
\hline \multirow{6}{*}{ Forearm without atopic changes } & \multicolumn{5}{|c|}{$\begin{array}{c}\text { Hydration level } \\
M(\mathrm{Q} 25-\mathrm{Q} 75)\end{array}$} \\
\hline & $29.9(28.1-32.3)$ & $28.1(22.4-29.4)$ & $28.2(25.8-30.3)$ & $23.5(14.5-30.1)$ & NS \\
\hline & \multicolumn{5}{|c|}{$\begin{array}{l}\text { Sebum level } \\
M(\mathrm{Q} 25-\mathrm{Q} 75)\end{array}$} \\
\hline & $1(0-1)$ & $1(1-2)$ & $0.5(0-1)$ & $0(0-0)$ & $\begin{array}{l}4 \text { vs. } 1 \\
0.043\end{array}$ \\
\hline & \multicolumn{5}{|c|}{$\begin{array}{c}\text { pH level } \\
M(\mathrm{Q} 25-\mathrm{Q} 75)\end{array}$} \\
\hline & $5.6(5.2-6.1)$ & $5.4(5.1-5.9)$ & $5.4(4.5-6.0)$ & $5.7(4.8-6.0)$ & NS \\
\hline \multirow{8}{*}{ Hand with atopic changes } & \multicolumn{5}{|c|}{$\begin{array}{l}\text { Hydration level } \\
M(\mathrm{Q} 25-\mathrm{Q} 75)\end{array}$} \\
\hline & \multirow[t]{3}{*}{$10(8-12.1)$} & \multirow[t]{3}{*}{$10.5(9.4-13.5)$} & \multirow[t]{3}{*}{$9.9(7.9-16.4)$} & \multirow[t]{3}{*}{$14.8(9.5-20.0)$} & $\begin{array}{l}2 \text { vs. } 1 \\
0.015\end{array}$ \\
\hline & & & & & $\begin{array}{l}3 \text { vs. } 1 \\
0.010\end{array}$ \\
\hline & & & & & $\begin{array}{l}4 \text { vs. } 1 \\
0.010\end{array}$ \\
\hline & \multicolumn{5}{|c|}{$\begin{array}{l}\text { Sebum level } \\
M(\mathrm{Q} 25-\mathrm{Q} 75)\end{array}$} \\
\hline & $1(0-1)$ & $1(0-2)$ & $0(0-3)$ & $1(0-1)$ & NS \\
\hline & \multicolumn{5}{|c|}{$\begin{array}{c}\mathrm{pH} \text { level } \\
M(\mathrm{Q} 25-\mathrm{Q} 75)\end{array}$} \\
\hline & $5.8(5.5-5.9)$ & $5.6(5.6-6.0)$ & $5.5(5.0-6.08)$ & $5.6(5.3-5.8)$ & NS \\
\hline
\end{tabular}

1-4: measurement number; vs.: versus; NS: nonstatistical; $M$ : median; Q25-Q75: the value of the lower and the upper quartile. $p<0.05$.

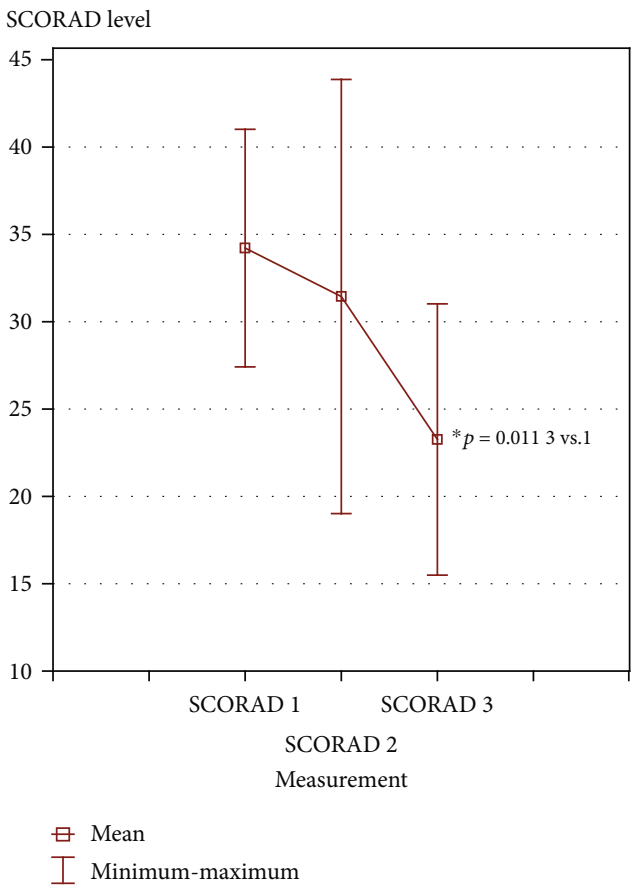

FIGURE 3: SCORAD index before the first cryotherapy treatment (1), after the 15th treatment (2), and 3 weeks after the last cryotherapy treatment (3). turn, other studies by Stanek et al. [17] also in the group of patients with AS additionally observed a decrease in markers of oxidative stress and changes in the activity of some antioxidative enzymes and in nonenzymatic antioxidant parameters. However, in the study of Banfi et al. [18] after a short-term WBC session in athletes, a decrease in creatine kinase and lactate dehydrogenase was observed along with a decrease in the inflammatory cytokine and an increase in the anti-inflammatory cytokine. Pournot et al. [19] explain the anti-inflammatory effect of vasoconstriction at the muscular level and the decrease in the inflammatory cytokine activity. The antioxidant activity of WBC treatments is also confirmed by Stanek et al. [20]. In the subjects (healthy men) studied, a decrease in the concentration of most parameters of oxidative stress was accompanied by an increase in the concentration of nonenzymatic antioxidants (total status of antioxidants and uric acid). Similar changes were observed by Lubkowska et al. [21]. Repeated WBC treatments cause changes in the state of peroxides and antioxidants, and these changes may depend on the number of treatments. WBC treatments also have an analgesic effect $[22,23]$, which could improve the skin condition of the subjects in our studies and contribute to lowering the SCORAD index.

The present study has some limitations. The study should involve a larger number of $\mathrm{AD}$ patients, both with and without WBC treatments. 


\section{General Conclusion}

Based on our own research, WBC can be an effective, supporting method in the treatment of AD. However, there is still little data in the scientific literature on the effect of cryogenic temperatures on skin parameters in patients with $\mathrm{AD}$.

\section{Data Availability}

The data used to support the findings of this study are included within the article.

\section{Conflicts of Interest}

The authors declare that there is no conflict of interests regarding the publication of this paper.

\section{Funding}

The study was conducted within the scope of a grant awarded to the University of Physical Education in Krakow (Poland) with the following numbers: 170/BS/KRK/2018 and $123 / \mathrm{BS} / \mathrm{KF} / 2017$.

\section{Acknowledgments}

We would like to thank the students of the University School of Physical Education in Krakow, Poland (D. Wysopal, I. Stachura, and K. Czekaj) for their help in research and all the volunteers who participated in this study. The publication was financed under the program of the Ministry of Science and Higher Education under the name "Regional Initiative of Excellence" in the years 2019-2022 (project number $022 /$ RID/2018/19 in the amount of PLN 11,919,908).

\section{References}

[1] T. Knor, A. Meholjić-Fetahović, and A. Mehmedagić, "Stratum corneum hydration and skin surface $\mathrm{pH}$ in patients with atopic dermatitis," Acta Dermatovenerologica Croatica, vol. 19, no. 4, p. 243, 2011.

[2] W. Silny, M. Czarnecka-Operacz, W. Gliński, Z. Samochocki, and D. Jenerowicz, "Atopowe zapalenie skóry - współczesne poglądy na patomechanizm oraz metody postępowania diagnostyczno-leczniczego. Stanowisko grupy specjalistów Polskiego Towarzystwa Dermatologicznego [Atopic dermatitis - contemporary views on the pathogenetic mechanism and methods of diagnostic and therapeutic. The position of a group of specialists of the Polish Society of Dermatology]," Postępy Dermatologii $i$ Alergologii, vol. 27, no. 5, pp. 365383, 2010.

[3] A. J. Sybilski, "Skóra - najważniejszy narząd naszego ciała. Dbajmy o nią! [Skin - the most important organ of our body. Let's care for the skin!]," Pediatria i Medycyna Rodzinna, vol. 8, no. 4, p. 376, 2012.

[4] K. Halvarsson and M. Loden, "Increasing quality of life by improving the quality of skin in patients with atopic dermatitis," International Journal of Cosmetic Science, vol. 29, no. 2, pp. 69-83, 2007.

[5] D. Chomiczewska, M. Kieć-Świerczyńska, and B. Kręcisz, "Irritant contact dermatitis. Part III. Non-invasive methods to assess biophysical properties of the skin," Medycyna Pracy, vol. 61, no. 4, pp. 457-466, 2010.

[6] M. L. Kmieć, “Znaczenie pomiarów parametrów czynnościowych skóry w ocenie funkcji bariery naskórkowej [The importance of measurement parameters in the assessment of functional skin barrier function of the skin]," Journal of Health Study and Medicine, vol. 2, pp. 23-50, 2016.

[7] M. Czarnecka-Operacz, "Nowy algorytm leczenia atopowego zapalenia skóry o łagodnym i średnim nasileniu objawów klinicznych: miejscowe stosowanie pimekrolimusu w kremie $1 \%$ [A new algorithm for the treatment of atopic dermatitis, mild and moderate clinical signs: topical use of pimecrolimus cream 1\%]," Alergoprofil, vol. 10, no. 4, p. 6, 2014.

[8] M. Kepinska, J. Gdula-Argasinska, Z. Dabrowski et al., "Fatty acids composition in erythrocyte membranes of athletes after one and after a series of whole body cryostimulation sessions," Cryobiology, vol. 74, pp. 121-125, 2017.

[9] T. Klimenko, S. Ahvenainen, and S. L. Karvonen, "Wholebody cryotherapy in atopic dermatitis," Archives of Dermatology, vol. 144, no. 6, pp. 806-808, 2008.

[10] J. M. Hanifin and G. Rajka, "Diagnostic features of atopic dermatitis," Acta Dermato-Venereologica, vol. 92, pp. 44-47, 1980.

[11] D. Chomiczewska, M. Kieć-Świerczyńska, and B. Kręcisz, "Kontaktowe zapalenie skóry z podrażnienia część I. Epidemiologia, etiopatogeneza i obraz kliniczny [Contact dermatitis from irritation. Part I. Epidemiology, etiopathogenesis and clinical presentation]," Medycyna Pracy, vol. 59, no. 5, pp. 409-419, 2009.

[12] A. Skrzek, A. Ciszek, D. Nowicka, and A. Dębiec-Bąk, "Evaluation of changes in selected skin parameters under the influence of extremely low temperature," Cryobiology, vol. 86, pp. 19-24, 2019.

[13] M. Kieć-Świerczyńska, B. Dudek, B. Kręcisz et al., "Rola czynników psychologicznych i zaburzeń psychicznych w chorobach skóry [The role of psychological factors and mental disorders in skin diseases]," Medycyna Pracy, vol. 57, no. 6, pp. 551-555, 2006.

[14] J. Rymaszewska, K. Urbańska, D. Szcześniak et al., "Krioterapia ogólnoustrojowa - obiecująca forma potencjalizacji leczenia zaburzeń depresyjnych [Whole-body cryotherapy - promising add-on treatment of depressive disorders]," Psychiatria Polska, vol. 53, pp. 1-15, 2018.

[15] E. Miller, Ł. Markiewicz, J. Saluk, and I. Majsterek, "Effect of short-term cryostimulation on antioxidative status and its clinical applications in humans," European Journal of Applied Physiology, vol. 112, no. 5, pp. 1645-1652, 2012.

[16] A. Stanek, G. Cieślar, J. Strzelczyk et al., "Influence of cryogenic temperatures on inflammatory markers in patients with ankylosing spondylitis," Polish Journal of Environmental Studies, vol. 19, no. 1, pp. 167-175, 2010.

[17] A. Stanek, A. Cholewka, T. Wielkoszyński, E. Romuk, and A. Sieroń, "Whole-body cryotherapy decreases the levels of inflammatory, oxidative stress, and atherosclerosis plaque markers in male patients with active-phase ankylosing spondylitis in the absence of classical cardiovascular risk factors," Mediators of Inflammation, vol. 2018, Article ID 8592532, 11 pages, 2018.

[18] G. Banfi, G. Melegati, A. Barassi et al., "Effects of whole-body cryotherapy on serum mediators of inflammation and serum muscle enzymes in athletes," Journal of Thermal Biology, vol. 34, no. 2, pp. 55-59, 2009. 
[19] H. Pournot, F. Bieuzen, J. Louis et al., "Time-course of changes in inflammatory response after whole-body cryotherapy multi exposures following severe exercise," PLoS One, vol. 6, no. 7, p. e22748, 2011.

[20] A. Stanek, K. Sieroń-Stołtny, E. Romuk et al., "Whole-body cryostimulation as an effective method of reducing oxidative stress in healthy men," Advances in Clinical and Experimental Medicine, vol. 25, no. 6, pp. 1281-1291, 2016.

[21] A. Lubkowska, B. Dołęgowska, and Z. Szyguła, "Whole-body cryostimulation - potential beneficial treatment for improving antioxidant capacity in healthy men - significance of the number of sessions," PLoS One, vol. 7, no. 10, p. e46352, 2012.

[22] A. Stanek, A. Cholewka, J. Gadula, Z. Drzazga, A. Sieron, and K. Sieron-Stoltny, "Can whole-body cryotherapy with subsequent kinesiotherapy procedures in closed type cryogenic chamber improve BASDAI, BASFI, and some spine mobility parameters and decrease pain intensity in patients with ankylosing spondylitis?," BioMed Research International, vol. 2015, Article ID 404259, 11 pages, 2015.

[23] J. Rivera, M. J. Tercero, J. S. Salas, J. H. Gimeno, and J. S. Alejo, "The effect of cryotherapy on fibromyalgia: a randomised clinical trial carried out in a cryosauna cabin," Rheumatology International, vol. 38, no. 12, pp. 2243-2250, 2018. 